JP3I (Jurnal Pengukuran Psikologi dan Pendidikan Indonesia), 7(I), 2018, 4I-48

D0l: http://dx.doi.org/10.15408/p3i.v7il.12107

http://journal.uinjkt.ac.id/index.php/jp3i

\title{
UJI VALIDITAS KONSTRUK SELF CONTROL TERHADAP PROKRASTINASI AKADEMIK DENGAN METODE CONFIRMATORY FACTOR ANALYSIS (CFA)
}

\author{
Nurfaizin \\ UIN Syarif Hidayatullah Jakarta \\ Nurfaizin76@gmail.com
}

\begin{abstract}
The purpose of this study was to examine the construct validity of self-control which was used as a measurement tool related to academic procrastination. In this study, the five aspects of Sarafino were incorporated (in Averill, I973), namely: I. Behavior control, 2. Cognitive control, 3. Decisional control, 4. Information control, 5. Retrospective control. With 45 items the subject of this study were students of Syarif Hidayatullah State Islamic University Jakarta from 2006-2008 who were preparing a thesis, the number of samples in this study were I22 people. The data analysis method used in this study is confirmatory factor analysis (CFA) with the help of listel 8.70 software. Based on calculations using the CFA method it can be concluded that all dimensions require modification of the measurement model to obtain a fit value.
\end{abstract}

Kata Kunci: Test the Validity of the construct of self-control and locus of control for academic procrastination using the Confirmatory Factor Analysis (CFA) Method.

\begin{abstract}
Abstrak
Tujuan dari penelitian ini adalah untuk menguji validitas konstruk dari self-control yang digunakan sebagai alat ukur yang berhubungan dengan prokrastinasi akademik. dalam penelitian ini adalah mengungankan lima aspek dari Sarafino (dalam Averill,1973) yaitu:I.Behavior control, 2. Cognitive control, 3. Decisional control, 4. Informationl control, 5. Retrospective control. Dengan 45 item subjek penelitian ini adalah mahasiswa UIN Syarif Hidayatullah Jakarta dari 2006-2008 yang sedang menyusun skripsi, jumlah sampel dalam penelitian ini sebanyak I22 orang. Metode analisis data yang digunakan dalam penelitian ini adalah confirmatory factor analysis (CFA) dengan bantuan software lisrel 8.70. Berdasarkan perhitungan dengan metode CFA dapat disimpulkan bahwa semua dimensi memerlukan modifikasi model pengukuran untuk memperoleh nilai fit.

Kata Kunci: Uji Validitas Konstruk self-control dan locus of control terhadap prokrastinasi akademik dengan Metode Confirmatory Factor Analysis (CFA).
\end{abstract}




\section{Pendahuluan}

Lazarus (dalam Thalib, 2010) menjelaskan bahwa kontrol diri individu mengambarkan keputusan individu melalui pertimbangan kognitif untuk menyatukan perilaku yang telah disusun guna meningkatkan hasil dan tujuan tertentu sebagaimana yang di inginkan. Messina dan Messina (dalam Gunarsa, 2006) menyatakan selfcontrol adalah seperangkat tingkah laku yang berfokus pada keberhasilan mengubah diri sendiri. Keberhasilan menangkalkan kerusakan diri (self-destructive) perasaan mampu pada diri sendiri, perasaan mandiri (autonomy) atau bebas dari pengaruh orang lain, kebebasan menentuksn tujuan, kemampuan untuk memisahkan perasaan dan pikiran rasional, serta seperangkat tingkah laku yang berfokus pada tangung jawab atas diri sendiri.

Sarafino (1994) menjelaskan bahwa kontrol diri merupakan kemampuan seseorang untuk membuat keputusan dan mengambil langkah-langkah yang efektif untuk mendapatkan hasil yang diinginkan dan menghindari hasil yang tidak diinginkan.

Sarafino (dalam Avirell, 1973) membagi kontrol diri (self-control) dalam lima aspek yaitu:

\section{a). Behavior control}

Kontrol perilaku merupakan kesiapan tersedianya suatu respons yang dapat secara langsung memengaruhi atau memodifikasi suatu keadaan yang tidak menyenangkan (dalam Averill, I973) Kontrol perilaku ada dua jenis yaitu pertama, mengatur pelaksanaan (regulated administration) yaitu kemampuan dalam mengatur dan menentukan siapa yang mengendalikan situasi atau keadaan.Kedua, kemampuan memodifikasi stimulus (stimulus modification) kemampuan untuk mengetahui bagaimana dan kapan suatu stimulus yang tidak dikehendaki terjadi.

\section{b) Cognitive control}

Kontrol kognitif merupakan kemampuan dalam mengolah informasi yang tidak diinginkan dengan cara menginterpretasi, menilai, atau menghubungkan suatu kejadian dalam suatu kerangka kognitif sebagai adaptasi psikologis atau mengurangi tekanan. (dalam Averill, 1973). Aspek ini terdiri dua komponen yaitu; memperoleh informasi dan menilai informasi. Dengan informasi yang dimiliki individu terkait suatu kejadian yang tidak menyenangkan, maka individu dapat mengantisipasinya dengan berbagai pertimbangan serta bisa menilai dan menafsirkan kejadian tersebut.

\section{c) Decisional control}

Merupakan kesempatan untuk memilih antara prosedur alternative atau cara bertindak (dalam Averill, 1973). Mengontrol keputusan adalah kemampuan individu untuk memilih hasil atau suatu tindakan berdasarkan pada sesuatu yang diyakini atau disetujuinya. Keputusan tindakan yang tidak didasarkan pada pertimbangan yang matang akan mengakibatkan kecemasan pada individu.

\section{d) Informational control}

Kontrol informasi merupakan waktu yang tepat untuk mengetahui lebih banyak tentang tekanan-tekanan apa saja yang terjadi dan konsekuensi selanjutnya. Infomasi kontrol diri dapat mengurangi tekanan dengan meningkatkan kemampuan individu untuk memprediksi dan mempersiapkan atas apa yang akan terjadi dengan ketakutan-ketakutan yang sering dimiliki sesorang yang tidak terduga.

\section{e) Retrospection control}

Kemampuan menilai peristiwa dari segi positif adalah keyakinan tentang apa dan siapa yang akan menyebabkan peristiwa yang penuh dengan stress setelah hal itu terjadi, kemampuan individu untuk mengolah informasi yang tidak diinginkan dengan cara menginterpretasi, menilai atau menggabungkan suatu kejadian dalam suatu kerangka kognitif sebagai adaptasi psikologis untuk mengurangi tekanan. 


\section{Metode}

Dalam penelitian ini yang dijadikan populasi adalah mahasiswa UIN Syarif Hidayatullah Jakarta dari angkatan 2006-2008 yang menyusun skripsi dengan Jumlah sampel pada penelitian ini I22 mahasiswa dengan menggunakan metode non-probability sampling dan menggunakan teknik insidental sampling adalah teknik penentuan sampel bergunakka sabagai sampel.

\section{Alat ukur Penelitian}

Skala ukur yang digunakan untuk mengukurself-controlyang terdiri dari 45 pernyataan yang disusun berdasarkan aspek-aspek self-controldari Sarafino (dalam Averill, 1973) yaitu: behavior control, cognitive control, decisional control, informational control dan retrospective control.

\section{Uji validitas konstruk}

Untuk menguji validitas alat ukur yang digunakan dalam penelitian ini, peneliti menggunakan confirmatory factor analysis (CFA) dengan software Lisrel 8.7. Adapun langkah-langkah yang dilakukan adalah sebagai berikut:

I. Dilakukan uji CFA dengan model unidimensional (satu faktor) dan dilihat nilai Chi-Square yang dihasilkan. Jika nilai Chi-Square tidak signifikan $(\mathrm{p}>0.05)$ berarti semua item telah mengukur sesuai dengan yang diteorikan, yaitu hanya mengukur satu faktor saja. Jika ini terjadi maka analisis dilanjutkan pada tahap selanjutnya, yaitu melihat muatan faktor pada masing-masing item. Namun jika Chi-Square signifikan $(\mathrm{p}<0.05)$, maka diperlukan modifikasi terhadap model pengukuran tersebut.

2. Jika nilai Chi-Square signifikan, maka dilakukan modifikasi model pengukuran dengan cara mengestimasi korelasi antar kesalahan pengukuran pada beberapa item yang mungkin bersifat multidimensional. Ini berarti bahwa selain suatu item mengukur konstruk yang seharusnya diukur, juga dapat dilihat apakah item tersebut mengukur hal yang lain (mengukur lebih dari satu hal). Jika setelah beberapa kesalahan pengukuran dibebaskan untuk saling berkorelasi dan diperoleh model fit, maka model terkahir inilah yang akan digunakan pada langkah selanjutnya.

3. Setelah diperoleh model fit (unidimensional) maka dilihat apakah ada item yang muatan faktornya negatif. Melihat signifikan tidaknya item tersebut mengukur faktornya dilihat dari nilai $\mathrm{t}$ bagi koefisien muatan faktor item. Perbandingannya adalah ( $\mathrm{t}>\mathrm{I}, 96)$ maka item tersebut signifikan. Jika ada yang tidak signifikan dimana $(t<I, 96)$ maka item tersebut harus didrop atau tidak diikutsertakan dalam analisis perhitungan faktor skor.

Hasil Uji Validitas Konstruk aspek behavior control dari variabel self-control. Peneliti menguji apakah 8 item yang ada bersifat undimensional mengukur satu faktor yaitu behavior control. Dari hasil awal analisis CFA yang dilakukan, model satu faktor tidak fit dengan Chi-Square $=92,45, \mathrm{df}=44, \mathrm{P}$-value $=0,00003$, RMSEA $=0,095$. Namun setelah dilakukan modifikasi terhadap model, dimana kesalahan pengukuran pada item dibebaskan berkolerasi satu sama lainnya, maka diperoleh model fit dengan Chi-Square $=48,72$, df $=39$, P-value $=0,013675$, RMSEA $=0,045$. Nilai ini menyatakan P-value $<0,05$ (signifikan) yang artinya model dapat diterima. Dapat dillihat pada gambar 3.2

Selanjutnya yang perlu dilakukan oleh peneliti adalah melihat muatan fakor dari item-item pada skala perilaku kontrol (behavior control) dengan melihat nilai skor nilai t dan jenis muatan pada nili koefisiensi dari masing-masing item. Adapun tabel data muatan faktor dari item-item seperti berikut: 
Tabel I. Muatan Faktor Aspek Behavior Control

\begin{tabular}{|l|l|l|l|l|}
\hline Item & Koefisien & S.E & T & Sig \\
\hline I & 0.28 & 0.10 & 2.82 & $\mathrm{~V}$ \\
\hline $\mathbf{2}$ & 0.66 & 0.09 & 7.26 & $\mathrm{~V}$ \\
\hline $\mathbf{3}$ & 0.48 & 0.10 & 5.39 & $\mathrm{~V}$ \\
\hline $\mathbf{4}$ & 0.53 & 0.10 & 5.39 & $\mathrm{~V}$ \\
\hline $\mathbf{5}$ & -.0 .15 & 0.10 & -5.36 & $\mathrm{X}$ \\
\hline $\mathbf{6}$ & $-0.0 \mathrm{I}$ & 0.10 & -0.10 & $\mathrm{X}$ \\
\hline $\mathbf{7}$ & -0.46 & 0.10 & -4.57 & $\mathrm{X}$ \\
\hline $\mathbf{8}$ & -0.61 & 0.09 & -6.54 & $\mathrm{X}$ \\
\hline $\mathbf{9}$ & 0.40 & 0.10 & 4.11 & $\mathrm{~V}$ \\
\hline I0 & 0.44 & 0.10 & 4.55 & $\mathrm{~V}$ \\
\hline II & 0.26 & 0.10 & 2.61 & $\mathrm{~V}$ \\
\hline
\end{tabular}

\section{Ket: signifikan $(\mathrm{p}>\mathrm{I}, 96)$}

Dari tabel diatas dapat dilihat bahwa nilai t pada muatan faktor item 5, 6, 7 dan 8 tidak signifikan, sedangkan muatan faktor item yang lainnya signifikan. Artinya item 5, 6, 7 dan 8 akan didrop dan tidak diikutkan dalam perhitungan analisis statistik berikutnya.

Gambar I. Diagram Path Skala Aspek Perilaku control (Behavior Control)

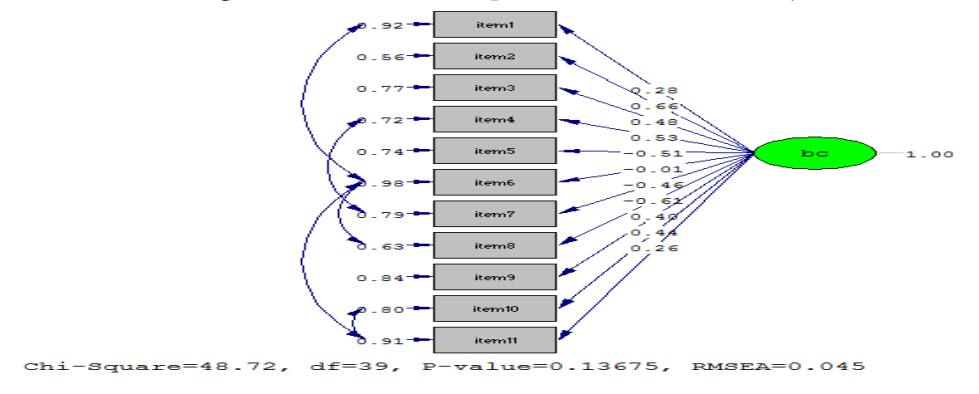

\section{Uji validitas skala self-control aspek cognitive control.}

Peneliti menguji apakah II item yang ada bersifat unidimensional mengukur satu faktor yaitu cognitive control. Dari hasil awal analisis CFA yang dilakukan, model satu faktor tidak fit dengan Chi-Square = I3I,24 $\mathrm{df}=44, \mathrm{P}$-value $=0,00000, \mathrm{RMSEA}=0,128$. Namun setelah dilakukan modifikasi terhadap model, dimana kesalahan pengukuran pada item dibebaskan berkolerasi satu sama lainnya, maka diperoleh model fit dengan Chi-Square $=50,60, \mathrm{df}=0,06734 \mathrm{P}$-value $=0,06734$, RMSEA $=0,055$. Nilai ini menyatakan $\mathrm{P}$-value $<0,05$ (signifikan), yang artinya model dapat diterima.

Gambar 2. Diagram Path Cognitif Control daria spekSelf-Control

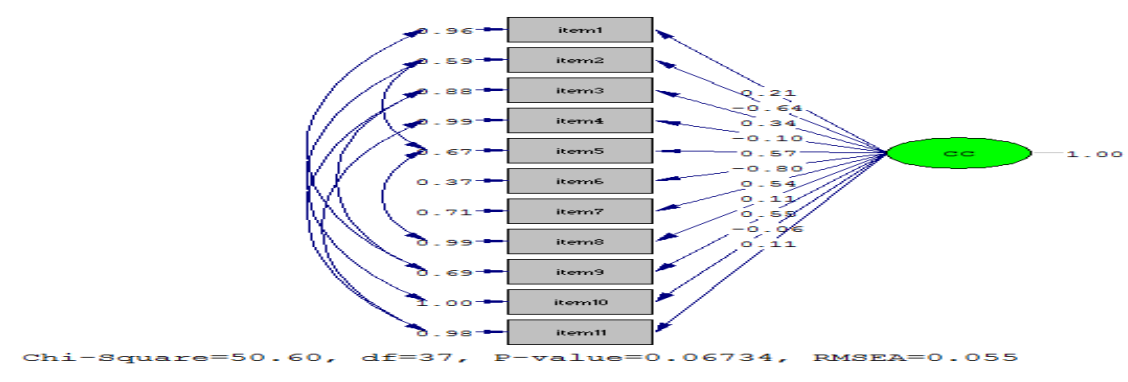


Selanjutnya yang perlu dilakukan oleh peneliti adalah melihat muatan fakor dari item-item pada skala cognitif control dengan melihat nilai skor nilai t dan jenis muatan pada nili koefisiensi dari masing-masing item. Adapun tabel data muatan faktor dari item-item pada skala cognitif control.

Tabel 2. Muatan faktor control cognitif

\begin{tabular}{|c|c|c|c|c|}
\hline Item & Kofesien & S.E & $\mathrm{T}$ & Sig \\
\hline I & $0.2 \mathrm{I}$ & 0.10 & 2.10 & $\mathrm{~V}$ \\
\hline 2 & -0.64 & 0.09 & -7.05 & $\mathrm{X}$ \\
\hline 3 & 0.34 & 0.10 & $3.5 \mathrm{I}$ & V \\
\hline 4 & -0.10 & 0.10 & -0.98 & $X$ \\
\hline 5 & 0.57 & 0.09 & 6.06 & V \\
\hline 6 & -0.80 & 0.08 & -9.60 & $\mathrm{X}$ \\
\hline 7 & 0.54 & 0.09 & 5.86 & V \\
\hline 8 & $0.1 \mathrm{I}$ & 0.10 & 1.09 & $\mathrm{X}$ \\
\hline 9 & 0.55 & 0.09 & 5.95 & V \\
\hline I0 & -0.06 & 0.10 & $-0.6 \mathrm{I}$ & $X$ \\
\hline II & O.I I & 0.10 & I.13 & $\mathrm{X}$ \\
\hline
\end{tabular}

\section{Ket : signifikan $(p>1,96)$.}

\section{Uji validitas skala self-control aspek decisional control}

Peneliti menguji apakah 8 item yang ada bersifat unidimensional mengukur satu faktor yaitu decisional control. Dari hasil awal analisis CFA yang dilakukan, model satu faktor tidak fit dengan Chi-Square $=83,12$, $\mathrm{df}=44, \mathrm{P}$-value $=0,00033$, RMSEA $=0,086$. Namun setelah dilakukan modifikasi terhadap model, dmana kesalahan pengukuran pada item dibebaskan berkolerasi satu sama lainnya, maka diperoleh model fit dengan Chi-Square $=55,69, \mathrm{df}=4 \mathrm{I}, \mathrm{P}$-value $=0,0626 \mathrm{I}$ RMSEA $=0,054$. Nilai ini menyatakan $\mathrm{P}$-value $<0,05$ (signifikan) yang artinya model dapat diterima.

Gambar 3. Diagram Path Skala Self-Control aspek Decisional Control

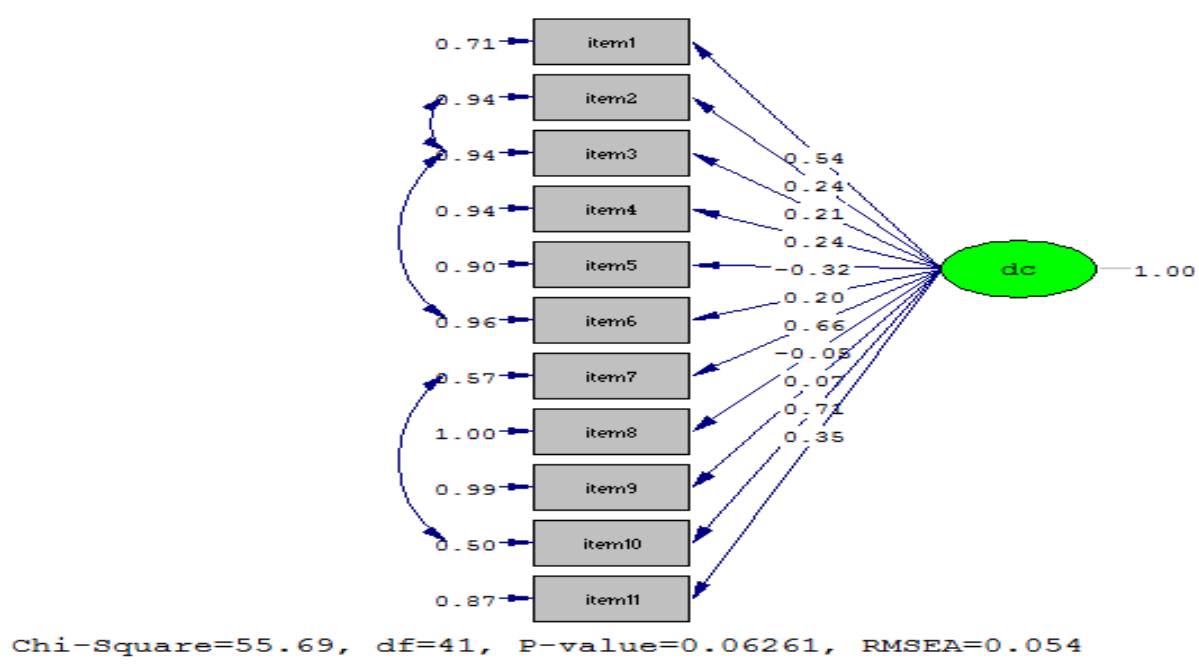


Selanjutnya yang perlu dilakukan oleh peneliti adalah melihat muatan fakor dari item-item pada skala decisional control dengan melihat nilai skor nilai t dan jenis muatan pada nilai koefisiensi dari masing-masing item. Adapun tabel data muatan faktor dari item-item pada decisional control sebagai berikut:

Tabel 3. Muatan Faktor Decisional Control

\begin{tabular}{|c|c|c|c|c|}
\hline Item & Koefesien & Santadar eror & Nilai t & Sig \\
\hline $\mathrm{I}$ & 0.54 & 0.10 & 5.30 & $\mathrm{~V}$ \\
\hline 2 & 0.24 & 0.10 & 2.46 & V \\
\hline 3 & $0.2 \mathrm{I}$ & 0.10 & 2.15 & V \\
\hline 4 & 0.24 & 0.10 & 2.39 & V \\
\hline 5 & -0.32 & 0.10 & -3.19 & $X$ \\
\hline 6 & 0.20 & 0.10 & $2.0 \mathrm{I}$ & V \\
\hline 7 & 0.66 & 0.10 & 5.35 & V \\
\hline 8 & -0.05 & 0.10 & -0.52 & $\mathrm{X}$ \\
\hline 9 & 0.07 & 0.10 & 0.74 & $X$ \\
\hline I0 & $0.7 \mathrm{I}$ & 0.12 & 5.80 & $\mathrm{X}$ \\
\hline II & 0.35 & 0.10 & 5.58 & $\mathrm{X}$ \\
\hline
\end{tabular}

\section{Ket : signifikan $(\mathrm{p}>1,96)$}

Dari tabel muatan faktor dapat dilihat bahwa dari I I item yang diujikan, item 5, 8, 9, I0 dan II memiliki muatan faktor yang tidak signifikan, artinya item 5, 8, 9, I0 dan I I tidak diikutkan dalam perhitungan analisis statistik berikutnya.

\section{Uji validitas skala self-control informational control}

Peneliti menguji apakah II item yang ada bersifat undimensional mengukur satu faktor yaitu informational control. Dari hasil awal analisis CFA yang dilakukan, model satu faktor tidak fit dengan Chi-Square =I9,69, $\mathrm{df}=9$, P-value =0,01992, RMSEA =0,099. Namun setelah dilakukan modifikasi terhadap model, dimana kesalahan pengukuran pada item dibebaskan berkolerasi satu sama lainnya, maka diperoleh model fit dengan Chi-Square $=12,36$, df =8, P-value =0,I3600, RMSEA =0,067. Nilai ini menyatakan P-value $<0,05$ (signifikan), yang artinya model dapat diterima.

Gambar 4. Diagram Path SkalaSelf-Control Kontrol Informasi(Infromasion Control

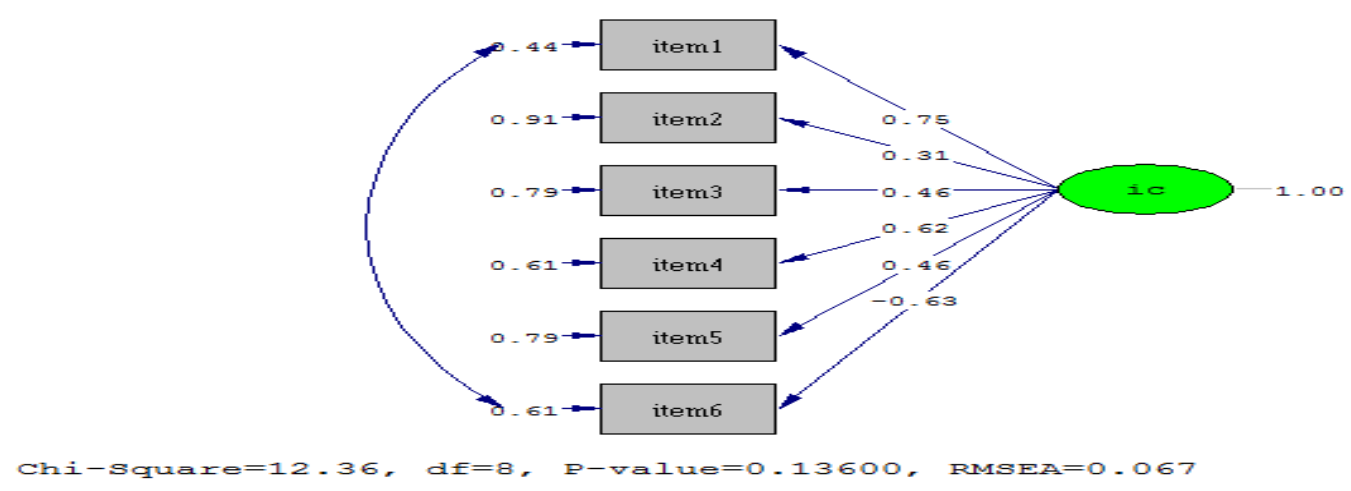


Selanjutnya yang perlu dilakukan oleh peneliti adalah melihat muatan faktor dari item-item pada skala informational controldengan melihat nilai skor nilai $\mathrm{t}$ dan jenis muatan pada nili koefisiensi dari masingmasing item. Adapun tabel data muatan faktor dari item-item pada informasi kontrol.

Tabel 4. Muatan Faktor Informational Control

\begin{tabular}{|l|l|l|l|l|}
\hline Item & Koefesien & S.E & T & Sig \\
\hline $\mathrm{I}$ & 0.75 & 0.10 & 7.14 & $\mathrm{~V}$ \\
\hline 2 & $0.3 \mathrm{I}$ & 0.10 & 3.14 & $\mathrm{~V}$ \\
\hline 3 & 0.46 & 0.10 & 4.80 & $\mathrm{~V}$ \\
\hline 4 & 0.62 & 0.10 & 6.53 & $\mathrm{~V}$ \\
\hline 5 & 0.46 & 0.10 & 4.76 & $\mathrm{~V}$ \\
\hline 6 & -0.63 & $0.1 \mathrm{I}$ & -5.67 & $\mathrm{X}$ \\
\hline
\end{tabular}

Ket : signifikan $(\mathrm{p}>\mathrm{I}, 96)$

Dari tabel diatas dapat dilihat bahwa nilai t pada muatan faktor item 6 tidak signifikan, sedangkan muatan faktor item yang lainnya signifikan.Artinya item 6 tidak diikutkan dalam perhitungan analisis statistik berikutnya.

\section{Uji validitas skala self-control dari aspek respective control.}

Peneliti menguji apakah II item yang ada bersifat undimensional mengukur satu faktor yaitu respective control. Dari hasil awal analisis CFA yang dilakukan, model satu faktor tidak fit dengan Chi-Square =2I,77, $\mathrm{df}=9$, P-value $=0,01035$, RMSEA =0,107. Namun setelah dilakukan modifikasi terhdap model, dimana kesalahan pengukuran pada item dibebaskan berkolerasi satu sama lainnya, maka diperoleh model fit dengan Chi-Square $=12,04$, df =8, P-value =0,I4949, RMSEA =0,065. Nilai ini menyatakan P-value $<0,05$ (signifikan), yang artinya model dapat diterima.

Gambar 5. Diagram Path self-control dari aspek respective control.

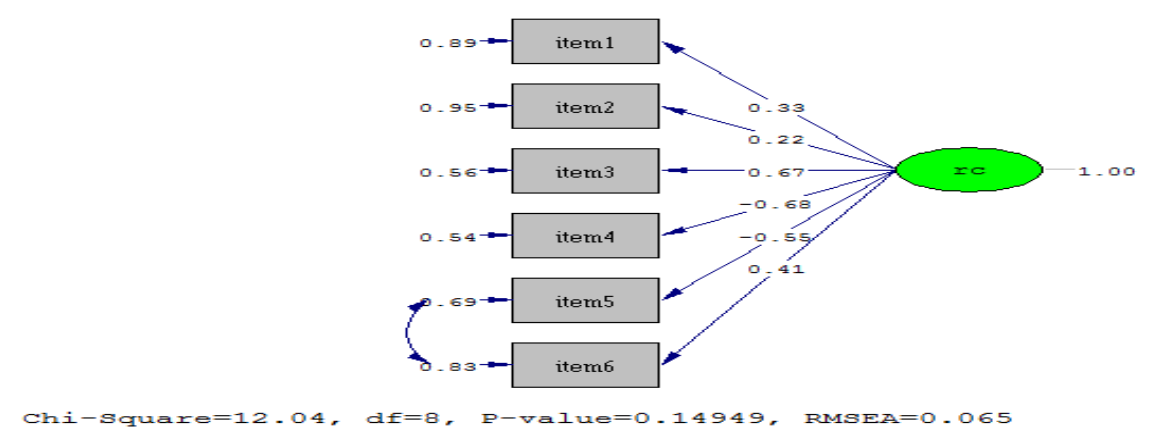

Selanjutnya yang perlu dilakukan oleh peneliti adalah melihat muatan fakor dari item-item pada skala respective control dengan melihat nilai skor nilai t dan jenis muatan pada nilai koefisiensi dari masing-masing item. Adapun tabel data muatan faktor dari item-item pada self-control dari aspek respective control.

Tabel 5. Muatan Faktor Aspek Respective Control

\begin{tabular}{|l|l|l|l|l|}
\hline Item & Koefesien & S.E & T & Sig \\
\hline I & 0.33 & $0 . I$ I & 3. I I & V \\
\hline 2 & 0.22 & 0.1 I & 2.09 & V \\
\hline 3 & 0.67 & 0.10 & 6.35 & V \\
\hline 4 & -0.68 & $0.1 \mathrm{I}$ & $-5.3 \mathrm{I}$ & $\mathrm{X}$ \\
\hline 5 & -0.55 & 0.10 & $-5.3 \mathrm{I}$ & $\mathrm{X}$ \\
\hline
\end{tabular}




\begin{tabular}{|l|l|l|l|l|}
\hline 6 & $0.4 \mathrm{I}$ & $0 . \mathrm{I}$ & 3.76 & $\mathrm{~V}$ \\
\hline
\end{tabular}

\section{Ket : signifikan $(p>1,96)$}

Dari tabeldi atas dapat dilihat bahwa nilai t pada muatan faktor item 4 dan 5 tidak signifikan, sedangkan muatan faktor item yang lainnya signifikan. Artinya bobot nilai pada item 4 dan 5 tidak ikut di analisis dalam penghitungan faktor skor.

\section{Penutup}

Hasil penelitian menunjukkan bahwa semua aspek dari self-control yaitu I.Behavior control, 2. Cognitive control, 3. Decisional control, 4. Informationl control, 5. Retrospective control. memerlukan modifikasi untuk mencapai model fit. Setelah melakukan analisis faktor terhadap lima aspek self-control menunjukkan bahwa alat ukur ini masih layak digunakan namun perlu dilakukan perbaikan dan pembaharuan terhadap itemitem yang bersifat multidimensional.

Dari hasil pengujian CFA menunjukkan bahwa terdapat banyak korelasi antar measurement error pada setiap item pada semua self-control. Hal ini menunjukkan bahwa item tersebut mengukur hal yang hendak diukur, ternyata juga mengukur hal yang lain (multidimensional).

Berdasarkan kesimpulan dan diskusi maka dapat disarankan bahwa:

I. Perlu dilakukan identifikasi terlebih dahulu untuk melihat item yang mengukur aspek self-control

2. Bagi peneliti selanjutnya disarankan untuk mengembangkan item lebih mendalam agar tidak melakukan modifikasi model fit, agar alat ukur yang digunakan benar-benar mengukur apa yang hendak diukur dan menghasilkan hasil yang akurat.

\section{Daftar Pustaka}

Averill. J (1973). Personal control over aversive stimuli and its relationsip to stress. University of Massachuselis. Psychological Bulletin. 80,(4), 286-303.

Gunarsa, Singgih (2006) Dari anak sampai usia lanjut. Jakarta PT.BPK Gunung mulia.

Sarafino,E.P (1994). Healty psyhcologogy : Biospsyhcosocial interaction. Second edition. New York: John Willey\& Sons,Inc.

Thalib, S, B (2010). Psikologi pendidikan berbasis analisis empiris aplikataif. Jakarta Kencana prenada media grup. 